\title{
Effect of Cutting Condition on the Surface Roughness Level of ST 42 Steel in Conventional Lathe Processes
}

\section{Pengaruh Cutting Condition Terhadap Tingkat Kekasaran Permukaan Baja ST 42 Pada Proses Bubut Konvensional}

Doni Hamdani ${ }^{*}{ }^{*}$ Irzal $^{1}$, Nofri Helmi ${ }^{1}$, Rifelino $^{1}$

\begin{abstract}
Cutting conditions carried out in the turning or manufacturing process will have an impact on the quality of the components produced. One indicator of the quality of turning or manufacturing is surface roughness on the object. The purpose of this research is to determine the ratio of the level of surface roughness of ST 42 steel after conventional turning with different cutting conditions by varying the main cutting angle and cutting depth and its effect on the rate of wasted material (MRR). The main cutting angles used in this study were $\mathrm{Kr}$ 90, 80, 70 and variations in cutting depth of $0.5 \mathrm{~mm}, 1 \mathrm{~mm}, 1.5 \mathrm{~mm}$. Based on the data obtained it can be concluded that the greater the depth of cutting, the higher the rate of wasted material (MRR) and the higher the level of surface roughness and vice versa.
\end{abstract}

\section{Keywords}

cutting conditions, main cutting angle, cutting depth, and surface roughness.

\begin{abstract}
Abstrak
Kondisi pemotongan yang dilakukan pada proses pembubutan atau manufaktur akan berdampak terhadap kualitas komponen yang diproduksi. Salah satu indikator dari kualitas hasil pembubutan atau manufaktur adalah kekasaran permukaan pada benda tersebut. Adapun penelitian ini bertujuan untuk menentukan perbandingan tingkat kekasaran permukaan baja ST 42 pasca pembubutan konvensional dengan kondisi pemotongan yang berbeda dengan memvariasikan sudut potong utama dan kedalaman pemotongan serta pengaruhnya terhadap laju bahan bahan terbuang (MRR). Sudut potong utama yang digunakan pada penelitian ini adalah $\mathrm{Kr} 90,80,70$ serta variasi kedalaman pemotongan $0,5 \mathrm{~mm}, 1 \mathrm{~mm}, 1,5 \mathrm{~mm}$. Berdasarkan data yang didapat maka dapat disimpulkan bahwa semakin besar kedalaman pemotongan maka semakin tinggi laju bahan terbuang (MRR) dan semakin tinggi tingkat kekasaran permukaan maupun sebaliknya.
\end{abstract}

\section{Kata Kunci}

Kondisi pemotongan, sudut potong utama, kedalaman pemotongan, dan kekasaran permukaan.

\footnotetext{
${ }^{1}$ Pendidikan Teknik Mesin, Universitas Negeri Padang

Fakultas Teknik, Kampus UNP Air Tawar, Jl. Prof. Dr. Hamka, Padang, Sumatera Barat. Kode Pos 25132

*donihamdani150211@gmail.com

Submitted : April 06, 2020. Accepted : May 08, 2020. Published : September 01, 2020.
} 


\section{PENDAHULUAN}

Dengan semakin berkembangnya dunia industri manufaktur serta terus meningkatnya permintaan pasar terhadap produksi komponen mesin dalam industri pemesinan, harus diiringi dengan peningkatan kualitas hasil produksi. Standar dari menentukan kualitas dari hasil produksi adalah ketepatan ukuran dan kekasaran permukaan. Sehingga komponenkomponen tersebut dapat digunakan dalam jangka waktu yang lama. Dalam proses pembubutan agar mendapatkan hasil produksi dengan kualitas yang bagus, maka yang harus diperhatikan, faktor-faktor yang dapat mempengaruhi hasil pembubutan seperti berikut ini yaitu pahat bubut yang digunakan, jenis bahan yang akan dibubut, serta kondisi pemotongan yang digunakan dalam proses pembubutan. Kondisi pemotongan yang dilakukan pada penelitian ini dengan menvariasikan kedalaman pemotongan menggunakan sistem pemotongan orthogonal dan oblique cutting (sistem pemotongan orthogonal yaitu sistem pemotongan yang menggunakan $\mathrm{Kr} 90^{\circ}$ sedangkan sistem pemotongan oblique cutting yaitu sistem yang menggunakan $\mathrm{Kr}$ kecil $90^{\circ}$ pada penelitian ini menggunakan $\mathrm{Kr} 80^{\circ}$ dan $70^{\circ}$ ) dan laju pembuangan material (Material Rate Removal). Faktanya yang sering terjadi dilapangan banyak benda kerja yang dihasilkan menjadi bergelombang dan tidak rata. Hal ini disebabkan operator mesin bubut tidak terlalu memperhatikan kondisi pemotongan pada proses pembubutan. Dan untuk mendapatkan tingkat kekasaran yang telah ditentukan biasanya operator mengamplas benda kerja tersebut. Sedangkan prosedur pengamplasan tidak ada didalam proses pembubutan, hal ini dapat memperburuk kualitas dari hasil pembubutan. Namun hal ini sering terjadi di workshop dan di dunia industri pemesinan.

Pada penelitian sebelumnya yang membahas tentang pengaruh kondisi pemotongan baja karbon SC-1045 menggunakan pahat HSS terhadap kekasaran permukaan pada proses pembubutan dengan kecepatan potong yang berbeda sementara gerak makan dan kedalaman potongnya sama. Dalam penelitian tersebut dapat disimpulkan semakin tinggi kecepatan potong, maka semakin tinggi nilai kekasaran permukaan yang diperoleh dan semakin cepat waktu pemotongan.[1] Pada saat pembubutan banyak operator tidak mempedulikan kecocokan antara pemakaian sudut potong utama dan kedalaman pemotongan sesuai dengan kakakuan dan karakter dari benda kerja. Untuk itu, penelitian kali ini membahas suatu kondisi pemotongan dengan memvariasikan sudut potong utama dengan kedalaman pemotongan terhadap kekasaran permukaan benda pada proses pembubutan dikarenakan sudut potong utama tidak masuk pada elemen dasar pemesinan dalam suatu kondisi pemotongan maka penulis menambahkan apakah berpengaruh terhadap material rate removal (MRR) pada proses pembubutan yang dilakukan dengan menggunakan sudut potong utama dan kedalaman potong yang berbeda-beda sehingga berpengaruh terhadap kekasaran permukaan. Dan yang akan dilakukan pada penelitian ini adalah melakukan 9 kali pembubutan baja karbon rendah ST 42 dengan menggunakan pahat bubut HSS pada suatu kondisi pemotongan yang memvariasikan sudut potong utama dan kedalaman pemotongan sehingga berdampak pada MRR dan berpengaruh terhadap kekasaran permukaan.

\section{Mesin Bubut}

Mesin bubut adalah salah satu jenis mesin perkakas yang digunakan pada proses pemesinan dan berfungsi untuk menyayat permukaan luar dan dalam benda kerja menjadi bulat atau silinderis, konis, beralur, berigi, dan berulir [2]. Yang dimaksud proses pembubutan ialah proses dimana alat potong menyanyat permukaan dan dalam benda kerja sehingga berubah bentuk sesuai yang direncanakan. Setiap melakukan perencanaan pada proses pemesinan, ada ada beberapa elemen dasar pemesinan yang harus dipahami agar setiap produksi komponen mesin sesuai dengan ukuran obyektif yang ditentukan ,berikut elemen dasar proses pemesinan yaitu : kecepatan makan (feeding speed), kecepatan potong (cutting speed), kedalaman potong (depth of cut), waktu pemotongan (cutting time), kecepatan 
penghasilan geram [3]. Dalam setiap kondisi pemotongan yang dilakukan pada proses pembubutan (gambar 3) minimal ada tiga variabel proses yang ditetapkan harganya yaitu: kedalaman pemotongan (a), gerak makan (f) dan kecepatan potong(v), untuk menghasilkan produk dengan geometrik dan toleransi yang diminta. [3]

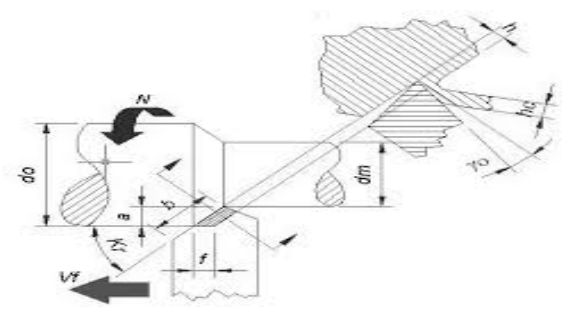

Gambar 1. Kondisi pemotongan pada proses bubut [3]

Model sistem pemotongan yang digunakan dalam proses membubut benda kerja ada dua macam yaitu orthogonal cutting dan oblique cutting. Sistem pemotongan orthogonal adalah dimana terjadi gaya yang berkerja pada proses pemotongan terhadap dua komponen dalam suatu bidang, sedangkan dalam sistem pemotongan oblique (miring) ada tiga komponen dalam sistem koordinat tertentu terjadi gaya total pemotongan(F) yang dianggap suatu ruang.[3]

\section{Pahat Bubut}

Pada proses pembubutan salah satu alat perkakas yang sangat penting digunakan untuk melakukan penyayatan/memotong pada benda kerja disebut dengan pahat bubut. Pada saat penyayatan, salah satu faktor terpenting yang menentukan terhadap kualitas yang dihasilkan dalam proses menyayat benda kerja (proses pemesinan) adalah geometri dari pahat bubut. Sebagai perkakas potong yang digunakan untuk memotong benda kerja pada proses bubut tentulah material dari pahat bubut harus lebih unggul dari material benda kerja, sehingga tahan terhadap temperatur tinggi akibat gesekan pemotongan, mempunyai sisi sayat tajam, tahan terhadap beban kejut atau benturan. Material yang dipakai untuk dijadikan pahat bubut antara lain baja karbon, HSS, paduan cor non fero, karbida, keramik, CBN, dan intan.[3]. Salah satu perkakas potong yang sering digunakan dalam proses bubut adalah pahat HSS. Unsur-unsur paduan yang terkandung didalam pahat HSS yaitu Wolfram, Cromium, Vanadium, Molybdenum, Cobalt. Sudut utama pahat (basic tool) adalah sudut- sudut yang ada pada mata pahat bubut atau geometri pahat (tool geometry). Sudut-sudut pahat bubut terdiri dari sudut bebas $(\mathrm{a})$, sudut geram $(\gamma)$, sudut miring $(\lambda)$, sudut potong utama $(\mathrm{Kr})$, sudut potong bantu (K'r).

Yang dimaksud dengan sudut potong utama adalah sudut yang berada garis perpotongan antara bidang geram dengan bidang utama pahat terhadap laju pemakanan (f), sedangkan yang menentukan besar kecilnya sudut potong utama adalah bentuk dari mata potong pahat dan pemasangan alat perkakas tersebut di mesin bubut. Peran sudut potong utama pada proses pembubutan, diantaranya: lebar dan tebal geram yang sebelum terpotong dapat ditentukan, serta menentukan panjang mata potong yang aktif atau panjang kontak antara geram dengan bidang pahat, dan menentukan gaya radial $F_{x}$. Apabila kedalaman dengan memperkecil sudut potong utama akan memperoleh keuntungan memperkecil tebal geram sebelum terpotong $h$ dan memperbesar lebar geram $b$, sebagai rumus berikut: $h=f \sin K r$ dan a/sin $\mathrm{Kr}$.

Pemakaian sudut potong utama yang kecil tidak semestinya selalu menguntungkan, karena dalam pemakaian sudut potong utama yang terlalu kecil akan meningkatkan gaya radial $f_{x}$ yang sehingga terjadi lenturan dan besar ataupun getaran pada proses pembubutan dan apabila tidak cocok dengan material yang akan dibubut nanti dikhawatirkan menurunkan 
tingkat kualitas dari produksi karena kurangnya keakuratan ukuran geometrik dan hasil pemotongannya terlalu kasar. Oleh karena itu, tergantung kekakuan benda kerja dan pahat serta cara pencekaman benda kerja serta sudut akhir/geometri benda kerja, maka operator mesin dapat menentukan pahat dan sudut kr yang cocok atau sudut penenpatan datar G diganti sehingga sudut kerja Kr dapat diubah sampai mendapatkan harga yang sesuai.[3]

\section{Kekasaran Permukaan dan Pengukuran}

Permukaan yang halus merupakan salah satu karakteristik geometris yang menjadi acuan baik atau rendahnya tingkat kualitas suatu komponen(Sudji Munaji, 1980)[4]. Yang sebenarnya terjadi dilapangan tidak mungkin mendapatkan hasil pembubutan yang benarbenar halus atau sempurna, karena disebabkan oleh beberapa faktor diantaranya faktor manuasia (operator), getaran dari mesin yang digunakan, karena umur mesin. Akan tetapi, dengan kemajuan ilmu pengetahuan dan teknologi para ilmuan teknik mesin yang terus berupaya membuat mesin bubut dan perlengkapannya yang mampu memproduksi komponen dengan permukaan yang semakin halus dari sebelumnya, sesuai dengan standar ukuran yang berlaku dalam metrologi yang ditetapkan oleh para ahli pengukuran.

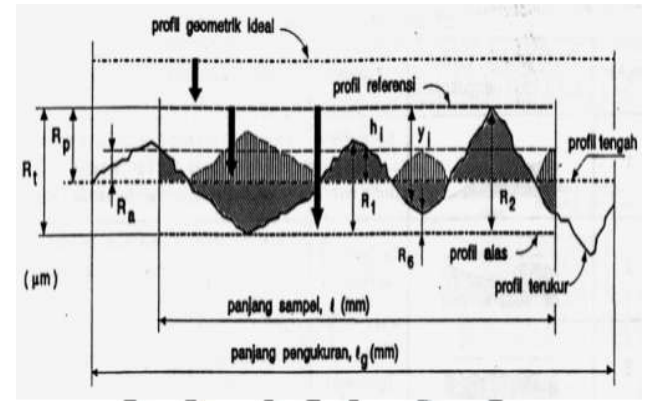

Gambar 2. Profil suatu permukaan [5]

Tabel 1. Kelas Kekasaran menurut standar ISO R.1302 [5]

\begin{tabular}{|c|c|c|c|c|}
\hline $\begin{array}{c}\text { Kelas } \\
\text { kekasaran }\end{array}$ & $\begin{array}{c}\text { Panjang } \\
\text { sampel }\end{array}$ & $\begin{array}{l}\text { Nilai C.L.A } \\
(\mu \mathrm{m})\end{array}$ & $\begin{array}{l}\text { Nilai Ra } \\
(\mu \mathrm{m})\end{array}$ & $\begin{array}{l}\text { Toleransi } \\
\mathrm{N}-25 \%+50 \%\end{array}$ \\
\hline N1 & \multirow[t]{2}{*}{0.08} & 1 & 0.025 & $0.02-0.04$ \\
\hline $\mathrm{N} 2$ & & 2 & 0.05 & 0.04-0.08 \\
\hline N3 & \multirow[t]{5}{*}{0.025} & 4 & 0.1 & $0.08-0.15$ \\
\hline $\mathrm{N} 4$ & & 8 & 0.2 & $0.15-0.3$ \\
\hline N5 & & 16 & 0.4 & $0.3-0.6$ \\
\hline N6 & & 32 & 0.8 & $0.6-1.2$ \\
\hline N7 & & 63 & 1.6 & $1.2-2.4$ \\
\hline N8 & \multirow[t]{2}{*}{0.8} & 125 & 3.2 & $2.4-4.8$ \\
\hline N9 & & 250 & 6.3 & $4.8-9.6$ \\
\hline N10 & \multirow[t]{2}{*}{2,5} & 500 & 12.5 & $9.6-18.75$ \\
\hline N11 & & 1000 & 25.0 & $18.75-37.5$ \\
\hline $\mathrm{N} 12$ & 8 & 2000 & 50.0 & $37.5-75.0$ \\
\hline
\end{tabular}

Biasanya komunikasi karakteristik permukaan atara perancang dan operator dilakukan melalui gambar teknik. Pada saat ini alat untuk mengukur kekasaran telah ada peningkatan mulai dari manual sampai alat yang otomatis yang menggunakan jarum sensor. Akan tetapi yang dimaksud dengan kekasaran permukaan adalah penyimpangan rata-rata aritmetik dari garis rata-rata dari kekasaran permukaan, defenisi ini digunakan untuk menentukan harga rata-rata dari kekasaran yang berbeda, sesuai dengan kebutuhan dari alat tersebut. Setiap nilai kekasaran memeiliki tingkat yang berbeda, berdasarkan yang ditetapkan oleh ISO (Tabel 
1) yaitu dimulai dari nilai yang terendah $\mathrm{N} 1$ dengan nilai $(\mathrm{Ra})$ 0,025 $\mu \mathrm{m}$ dan yang tertinggi N12 yaitu dengan nilai kekasaran $50 \mu \mathrm{m}$.

Pengujian kekasaran dapat dilakukan dengan berbagai cara yaitu, dapat dilakukan dengan cara meraba atau menggesek permukaan benda, namun dengan cara ini memeiliki kelemahan, yaitu hasil pengukuran tersebut tidak akurat dikarenakan sifatnya berdasarkan perasaan si pengukur. Berdasarkan proses pengujian yang dilakukan, maka cara mengukur kekasaran permukaan terdiri dari dua bagian yaitu : ada mengukur dengan cara tidak langsung seperti dengan cara meraba, (touch inspection), dengan melihat/mengamati (visual inspection), dengan mikroskop (microscopic inspection) dengan potografi permukaan (surface photographs) dan ada juga mengukur kekasaran secara langsung dapat dilakukan diantaranya dengan cara pada ujung alat ukurnya dilengkapi dengan peraba yang disebut dengan stylus. Salah satu alat yang digunakan untuk mengukur kekasaran permukaan dengan menggunakan stylus adalah Surface Tester SJ 201P Mitutoyo. [6]

\section{Baja}

Baja merupakan terdiri dari unsur paduan besi (Fe) dan karbon (C), dengan kandungan karbon kurang dari 2\%. Ada beberapa jenis dari baja paduan yaitu baja paduan rendah dan baja paduan tinggi. Baja paduan rendah terdapat hanya sedikit unsur paduan selain karbon dan sedikit mangan,sedangkan baja paduan tinggi secara sengaja dimasukkan unsur-unsur lain untuk meningkatkan karakteristik tertentu dari baja tersebut.[7]

\section{Baja Karbon}

Baja karbon adalah paduan antara besi dan karbon dengan sedikit $\mathrm{Si}, \mathrm{Mn}, \mathrm{P}, \mathrm{S}$ dan $\mathrm{Cu}$. Baja karbon dapat diklasifikasikan menjadi 3 jenis tergantung kadar karbon yang terkandung didalamnya, yaitu baja karbon rendah, baja karbon sedang, baja karbon tinggi. Baja karbon rendah adalah baja yang mengandung 0,05 s/d 0,30\% sedangkan baja karbon sedang mengandung karbon 0,30\% - 0,60\% dan baja karbon tinggi mengandung karbon 0,70\% $1,5 \%$ [8]. Material yang digunakan pada penelitian ini adalah baja ST 42 yang mempunyai kekuatan tarik antara $42 \mathrm{kgf} / \mathrm{mm}^{2}$ sampai $45 \mathrm{kgf} / \mathrm{mm}^{2}$. Baja ST 42 merupakan baja karbon rendah disebut juga baja lunak.

\section{METODE PENELITIAN}

Pada penelitian ini dilakukan dengan menggunakan jenis penelitian eksperimen, dimana penelitian ini dilakukan langsung terhadap benda uji atau spesimen,mulai dari menyiapkan alat dan bahan, mengerjakan atau membuat spesimen yang akan diuji serta melakukan pengujian secara langsung. Berdasarkan latar belakang masalah yang dijelaskan, maka tujuan dari eksperimen ini adalah untuk mengetahui suatu kondisi pemotongan yang bagaimana dapat menghasilkan kualitas yang baik terhadap tingkat kekasaran permukaan baja ST 42 pada proses bubut konvensional. Sebelum melakukan penelitian terlebih dahulu menguji kepastian baja ST 42, karena pada saat pembelian bahan tidak tercantum merek ST 42, untuk itu cara mengujinya dilakukan uji tarik dengan tiga benda sesuai dengan standar ASTM-E8.[9]

Dalam penelitian harus menentukan variabel yang akan diteliti, pada penelitian ini variabel yang diteliti adalah variabel bebas dan terikat (Tabel 2).

\section{Tabel 2 Variabel Penelitian}

\begin{tabular}{|c|l|}
\hline No & \multicolumn{1}{|c|}{ Variabel Penelitian } \\
\hline 1 & Variabel Bebas : Sudut Potong Utama yaitu $\mathrm{Kr} 90^{\circ}, 80^{\circ}, 70^{\circ}$ \\
\hline 2 & Variabel Terikat : Kekasaran Permukaan \\
\hline
\end{tabular}


Pada proses pembubutan ada beberapa parameter yang ditentukan harganya secara konstan berdasarkan material yang akan dibubut atau dikerjakn serta pahat bubut yang digunakan (Tabel 3).

Tabel 3. Parameter Konstan dan Pengerjaan Benda

\begin{tabular}{|c|c|c|c|}
\hline No & Parameter Konstan & No & Pengerjaan Benda \\
\hline 1 & $\begin{array}{l}\text { Cutting Speed }=39,62 \\
\mathrm{~m} / \mathrm{menit}\end{array}$ & 1 & $\begin{array}{l}\text { Pembubutan dilakukan dengan sudut potong } 90^{\circ} \text {, } \\
\text { kedalaman pemotongan } 0,5 \mathrm{~mm}\end{array}$ \\
\hline 2 & $\begin{array}{l}\text { Kecepatan putaran mesin }= \\
540 \mathrm{Rpm}\end{array}$ & 2 & $\begin{array}{l}\text { Pembubutan dilakukan dengan sudut potong } 90^{\circ} \text {, } \\
\text { kedalaman pemotongan } 1 \mathrm{~mm}\end{array}$ \\
\hline 3 & Feeding $=0,045 \mathrm{~mm} / \mathrm{put}$ & 3 & $\begin{array}{l}\text { Pembubutan dilakukan dengan sudut potong } 90^{\circ} \text {, } \\
\text { kedalaman pemotongan } 1,5 \mathrm{~mm}\end{array}$ \\
\hline 4 & Sudut bebas muka $10^{\circ}$ & 4 & $\begin{array}{l}\text { Pembubutan dilakukan dengan sudut potong } 80^{\circ} \text {, } \\
\text { kedalaman pemotongan } 0,5 \mathrm{~mm}\end{array}$ \\
\hline 5 & Sudut bebas samping $=10^{\circ}$, & 5 & $\begin{array}{l}\text { Pembubutan dilakukan dengan sudut potong } 80^{\circ} \text {, } \\
\text { kedalaman pemotongan } 1 \mathrm{~mm}\end{array}$ \\
\hline 6 & $\begin{array}{l}\text { Sudut geram samping }=14^{\circ} \\
-18^{\circ}\end{array}$ & 6 & $\begin{array}{l}\text { Pembubutan dilakukan dengan sudut potong } 80^{\circ} \text {, } \\
\text { kedalaman pemotongan } 1,5 \mathrm{~mm}\end{array}$ \\
\hline \multirow{3}{*}{7} & \multirow{3}{*}{$\begin{array}{l}\text { Sudut potong depan }=22^{\circ}- \\
25^{\circ}\end{array}$} & 7 & $\begin{array}{l}\text { Pembubutan dilakukan dengan sudut potong } 70^{\circ} \text {, } \\
\text { kedalaman pemotongan } 0,5 \mathrm{~mm}\end{array}$ \\
\hline & & 8 & $\begin{array}{l}\text { Pembubutan dilakukan dengan sudut potong } 70^{\circ} \text {, } \\
\text { kedalaman pemotongan } 1 \mathrm{~mm}\end{array}$ \\
\hline & & 9 & $\begin{array}{l}\text { Pembubutan dilakukan dengan sudut potong } 70^{\circ} \text {, } \\
\text { kedalaman pemotongan } 1,5 \mathrm{~mm}\end{array}$ \\
\hline
\end{tabular}

\section{Objek Penelitian}

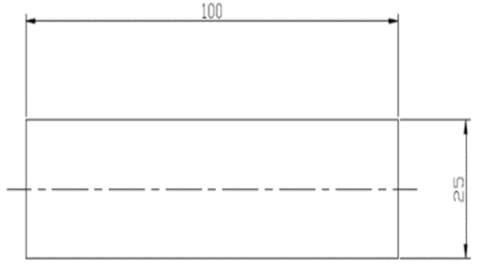

Gambar 3. Spesimen uji

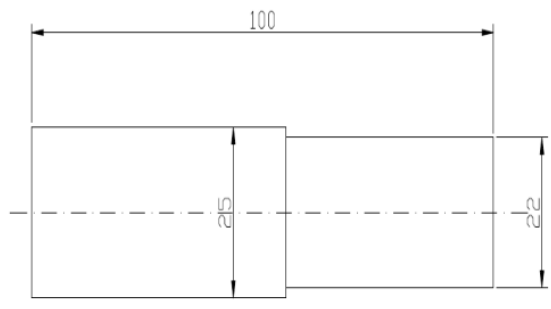

Gambar 5. a 1,5 mm

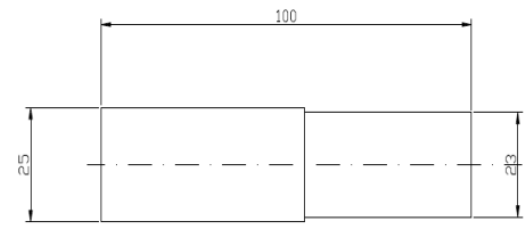

Gambar 4. a $1 \mathrm{~mm}$

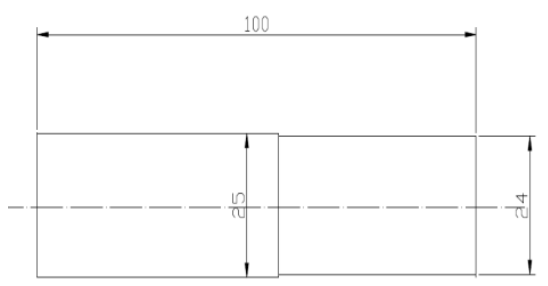

Gambar 6. $a$ 0,5 mm

Sebagai objek penelitian, digunakan 9 spesimen uji dengan panjang $100 \mathrm{~mm}$ dan diameter $25 \mathrm{~mm}$ (Gambar 3), setelah itu lakukan pembubutan 3 spesimen dengan kedalaman pemotongan $1 \mathrm{~mm}$ pada sudut potong utama yang berbeda (Gambar 4) selanjutnya bubut 3 
spesimen lagi dengan kedalaman pemotongan 1,5 mm (Gambar 5) dan lakukan pembubutan lagi 3 spesimen dengan kedalaman pemotongan 0,5 $\mathrm{mm}$ (Gambar 6) dengan $a$ adalah kedalaman pemotongan.

\section{Teknik Analisa Data}

Dalam manganalisa data pada penelitian ini menggunakan metode statistika deskriptif yaitu dengan teknik mengumpulkan informasi atau data dari hasil eksperimen secara langsung. Adapun data tersebut didapatkan dengan melakukan uji kekasaran permukaan permukaan benda dengan menggunakan alat ukur uji kekasaran (Surface Tester Mitutoyo SJ201P).

Rumus yang digunakan pada penelitian ini adalah :

Menghitung rata-rata kekasaran permukaan perspesimen $\left(\sum \mathrm{Ra}_{\mathrm{s}}\right)$

$$
\sum \mathrm{Ra}_{\mathrm{s}}=\frac{T 1+T 2+T 3 \ldots T n}{n}
$$

Keterangan $: \sum \mathrm{Ra}_{\mathrm{s}}=\mathrm{Rata}-$ rata kekasaran per spesimen

$$
\begin{aligned}
\mathrm{T} & =\text { Titik pengujian } \\
\mathrm{N} & =\text { Banyak Titik Pengujian [7] }
\end{aligned}
$$

Menghitung besar laju bahan terbuang (MRR)

$$
\mathrm{Z}=\text { f.a.v }
$$

$$
\text { Keterangan : } \begin{aligned}
\mathrm{Z} & =\text { Besar laju bahan terbuang } \\
f & =\text { Gerak makan } \\
a & =\text { Kedalaman Pemotongan } \\
v & =\text { Kecepatan Potong [2] }
\end{aligned}
$$

\section{HASIL DAN PEMBAHASAN}

\begin{tabular}{|c|c|c|c|c|c|c|c|c|}
\hline \multirow[t]{2}{*}{$\begin{array}{c}\text { Spesime } \\
\text { n ke }\end{array}$} & \multirow{2}{*}{$\begin{array}{l}\text { Sudut } \\
\text { Potong } \\
\text { Utama }\end{array}$} & \multirow{2}{*}{$\begin{array}{c}\text { Kedalaman } \\
\text { Pemotongan } \\
(\mathrm{mm})\end{array}$} & \multirow{2}{*}{$\begin{array}{c}\mathrm{MRR} \\
\left(\mathrm{Cm}^{3} / \mathrm{mn}\right. \\
\mathrm{t})\end{array}$} & \multicolumn{3}{|c|}{$\begin{array}{c}\text { Tingkat Kekasaran } \\
(\mu \mathrm{m})\end{array}$} & \multirow[t]{2}{*}{$\Sigma R a_{z}$} & \multirow[t]{2}{*}{$\begin{array}{c}\text { Kelas } \\
\text { kekasaran }\end{array}$} \\
\hline & & & & $\mathrm{T} 1$ & $\mathrm{~T} 2$ & T3 & & \\
\hline 1 & \multirow[t]{3}{*}{90} & $0,5 \mathrm{~mm}$ & 0,89 & 1,90 & 1,98 & 1,98 & 1,95 & N7 \\
\hline 2 & & $1 \mathrm{~mm}$ & 1,78 & 2,17 & 2,05 & 2,03 & 2,03 & N7 \\
\hline 3 & & $1,5 \mathrm{~mm}$ & 2,67 & 3,96 & 3,73 & 3,66 & 3,78 & N8 \\
\hline 4 & \multirow[t]{3}{*}{80} & $0,5 \mathrm{~mm}$ & 0,89 & 2,07 & 1,53 & 1,99 & 1,84 & N7 \\
\hline 5 & & $1 \mathrm{~mm}$ & 1,78 & 2,45 & 2,12 & 1,57 & 2,04 & N7 \\
\hline 6 & & $1,5 \mathrm{~mm}$ & 2,67 & 2,20 & 2,25 & 2,25 & 2,23 & N7 \\
\hline 7 & \multirow[t]{3}{*}{70} & $0,5 \mathrm{~mm}$ & 0,89 & 2,44 & 1,90 & 1,98 & 2,10 & N7 \\
\hline 8 & & $1 \mathrm{~mm}$ & 1,78 & 2,37 & 2,14 & 1,90 & 2,13 & N7 \\
\hline 9 & & $1,5 \mathrm{~mm}$ & 2,67 & 2,90 & 1,90 & 2,23 & 2,26 & N7 \\
\hline
\end{tabular}

\section{Data hasil uji tarik spesimen yang digunakan}

Data dari hasil pengujian atau eksperimen untuk mengetahui kekuatan tarik pada baja ST 42 dengan menggunakan standar ASTM E8 yang dilakukan di labor konstruksi di jurusan Teknik Sipil Universitas Negeri Padang adalah $43,64 \mathrm{kgf} / \mathrm{mm}^{2}$ sesuai dengan teori bahwasanya untuk baja ST 42 memiliki kekuatan tarik $42 \mathrm{kgf} / \mathrm{mm}^{2}-45 \mathrm{kgf} / \mathrm{mm}^{2}$.

\section{Data Hasil Penelitian}

Tabel 4. Data nilai kekasaran spesimen

\section{Pembahasan Hasil Penelitian}

Data hasil pengukuran kekasaran yang dilakukan pada baja ST 42 dengan menggunakan alat ukur Surface Tester Mitutoyo SJ 201P, maka data nilai kekasaran spesimen dalam satuan $(\mu \mathrm{m})$ sebagaimana yang tertera pada tabel 4 . Terlihat pada tabel setiap kondisi pemotongan 
yang ditentukan dengan sudut potong utama yang berbeda terjadi tingkat nilai kekasaran yang tidak sama. Pada kondisi pemotongan menggunakan $\mathrm{kr} 90^{\circ}$ dan kedalaman pemotongan rata-rata nilai kekasaran yang diperoleh yaitu $1,95 \mu \mathrm{m}$ pada kelas $\mathrm{N} 7$, sedangkan pda $\mathrm{kr} 80^{\circ}$ dan kedalaman pemotongan $0,5 \mathrm{~mm}$, maka rata - rata nilai kekasaran $1,84 \mu \mathrm{m}$ pada kelas $\mathrm{N} 7$ dan $\mathrm{kr} 70^{\circ}$ dan kedalaman pemotongan $0,5 \mathrm{~mm}$ maka diperoleh data rata - rata nilai kekasaran 2,10 $\mu \mathrm{m}$ pada kelas N7. Ini artinya sudut potong utama sangat berpengaruh terhadap kekasaran. Pemakaian sudut potong utama yang kecil tidak semestinya selalu menguntungkan, karena dalam pemakaian sudut potong utama yang terlalu kecil akan meningkatkan gaya radial $\mathrm{f}_{\mathrm{x}}$ yang akibatnya terjadi lenturan atau gesekan yang besar sehingga ketelitian ukuran geometri menjadi tidak akurat. Sedangkan setiap kondisi pemotongan dengan sudut potong utama yang ditentukan dengan pemotongan yang berbeda juga terjadi perbedaan rata-rata nilai kekasarannya. Pada kondisi pemotongan $\mathrm{kr} 90^{\circ}$ dengan kedalaman pemotongan $0,5 \mathrm{~mm}$ setelah dilakukan pengujian, maka rata-rata nilai kekasaran yang diperoleh yaitu $1,95 \mu \mathrm{m}$ pada kelas $\mathrm{N} 7$, sedangkan pada kedalaman pemotongan $1 \mathrm{~mm}$ dan $1,5 \mathrm{~mm}$ rata-rata nilai kekasaran yang diperoleh adalah $2,03 \mu \mathrm{m}$ dan $3,78 \mu \mathrm{m}$ pada kelas kelas N7 dan N8. Terlihat jelas pada kedalaman pemotongan $0,5 \mathrm{~mm}$ terlihat lebih halus dan lebih rendah tingkat kekasarannya dari pada kedalaman pemotongan $1 \mathrm{~mm}$ dan 1,5 mm.

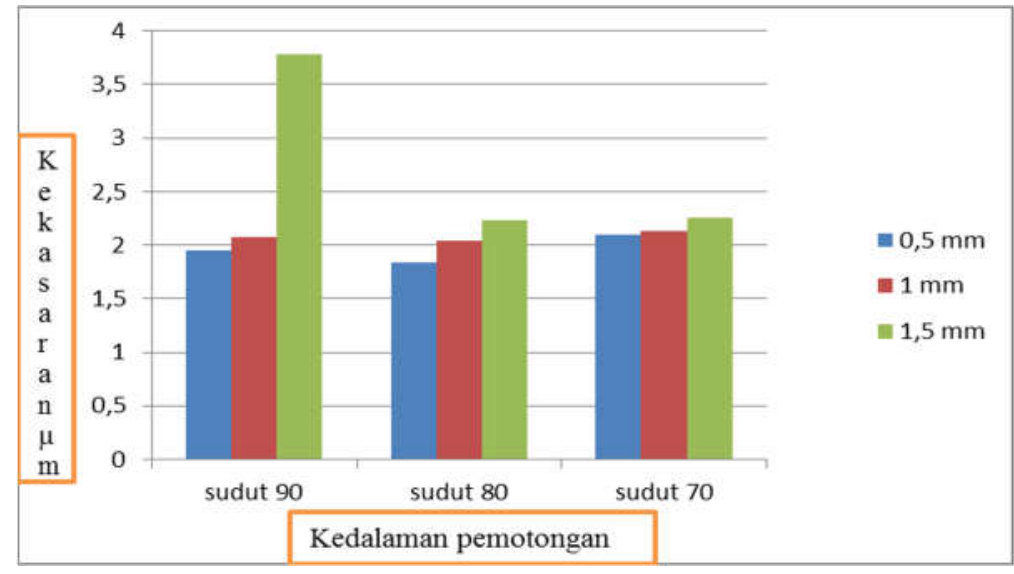

Gambar 7. Grafik pengaruh sudut potong utama dan kedalaman pemotongan terhadap kekasaran permukaan

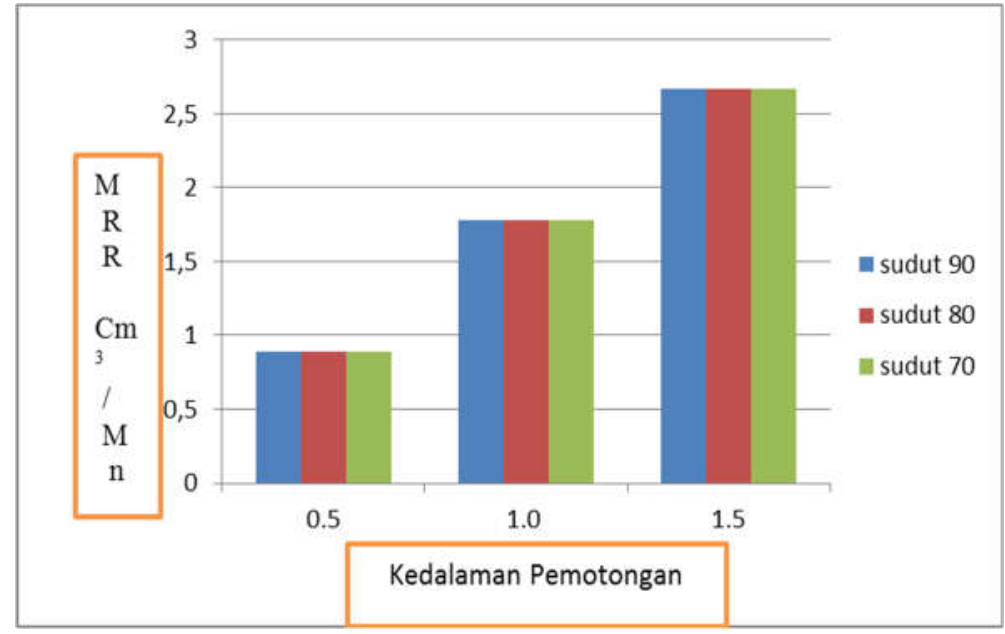

Gambar 8. Grafik pengaruh kedalaman pemotongan dan material rate removal dengan menggunakan sudut potong utama $90^{\circ}, 80^{\circ}, 70^{\circ}$. 
Berdasarkan grafik pada gambar 7 dapat dilihat rata-rata nilai kekasaran yang tertinggi yang didapatkan adalah 3,78 $\mu$ m dengan kelas kekasaran $\mathrm{N} 8$ yaitu pada spesimen ke 3 dengan kondisi pemotongan $\mathrm{kr} 90^{\circ}$ kedalaman pemotongan $1,5 \mathrm{~mm}$. Sedangkan rata-rata nilai kekasaran yang terendah dan tingkat kehalusan yang terbaik pada $\mathrm{kr} 80^{\circ}$ adalah $1,84 \mu \mathrm{m}$ dengan nilai kekasaran N7 yaitu pada spesimen ke 4 dengan kondisi pemotongan $\mathrm{kr} 80^{\circ}$, kedalaman pemotongan $0,5 \mathrm{~mm}$.

Dari gambar 8. Yang terlihat bahwa kedalaman pemotongan sangat berpengaruh terhadap laju bahan terbuang (MRR). Semakin kecil kedalaman pemotongan yang dilakukan maka semakin rendah laju bahan terbuang yang dihasilkan. Kekasaran permukaan biasanya dipengaruhi oleh sudut potong utama dan kedalaman pemotongan, maka manfaat dari penelitian ini adalah sebagai berikut : pada saat pembubutan dapat mengetahui sudut potong utama yang terbaik pada saat pembubutan dengan kedalaman pemotongan yang berbeda serta dampaknya terhadap material rate removal (MRR) sehingga berpengaruh terhadap kekasaran permukaan.

\section{SIMPULAN DAN SARAN}

\section{Simpulan}

Pada hasil proses bubut konvensional yang telah dilakukan menggunakan baja ST 42 dan pahat bubut HSS (High Speed Steel) dengan kondisi pemotongan yang berbeda dengan menggunakan sudut potong utama yang berbeda yaitu sudut potong utama $90^{\circ}, 80^{\circ}, 70^{\circ}$ Dapat disimpulkan pemakaian sudut potong utama 90 dengan kedalaman pemotongan 0,5 mm berbeda tingkat nilai kekasarannya dengan sudut potong utama 80 dan 70 . Pada penelitian ini sudut potong utama 80 yang menghasilkan tingkat kekasaran yang terendah dengan nilai kekasarannya $(1,84 \mu \mathrm{m})$ dan semakin besar kedalaman pemotongan yang dilakukan pada saat pembubutan, maka semakin besar laju bahan terbuang (MRR) dan berpengaruh terhadap tingkat kekasarannya .

\section{Saran}

Untuk mendapatkan kualitas hasil pembubutan konvensional dengan menggunakan bja ST 42 yang baik maka yang harus diperhatikan kondisi pemotongan yang digunakan. Ada beberapa elemen dasar kondisi pemotongan yang perlu diperlu diperhatikan antara lain, pilih kedalaman pemotongan yang sesuai dengan sudut potong utama pahat, karena kedalaman pemotongan sangat berpengaruh terhadap material rate removal sekaligus tingkat kekasaran material.

\section{DAFTAR RUJUKAN}

[1] M. R. Harahap,"Pengaruh Kondisi Pemotongan Baja Karbon SC-1045 Menggunakan Pahat HSS terhadap Kekasaran Permukaan Pada Proses Pembubutan,"Piston J. Ilm.Tek. Mesin Fak. Tek. UISU, vol. 2, no. 2, no. 2,pp. 69-76, Oct. 2018.

[2] Suarman Makhzu,"Teknologi Pemesinan", Padang, 2013.

[3] Taufiq Rochim, “Teori Dan Teknologi Proses Pemesinan”, Bandung : FTI-ITB. 2001."Spesifikasi, Metrologi \& Kontrol Kualitas Geometrik”. Bandung: ITB. 1993.

[4] Munadji, Sudji,"Dasar-Dasar Metrologi Industri”,Jakarta : 1980.

[5] Taufiq rochim," Spesifikasi Geometri Metrologi Industri dan Kontrol Kualitas, Bandung :Laboratorium Teknik Produksi dan Metrologi Industri". Bandung : ITB.2001.

[6] Dimas Abimanyu,"Pengaruh Kecepatan Pemakanan dan Kecepatan Putaran Spindle terhadap Tingkat Kekasaran Permukaan Aluminium Pada Proses Pembubutan Menggunakan Mesin Bubut Konvensional'.Skripsi Pendidikan Teknik Mesin Universitas Negeri Padang". Padang: 2019.

[7] Sofyan,Bondan T," Pengantar Material", Jakarta : Salemba Teknika, 2011. 
[8] Surdia,Tata. MS. Dan Salto,Shinoku,,'Pengetahuan Bahan Teknik",Jakarta : 1995

[9] ASTM-E-8-yr-13,"'Standart Test Methods for Tension Testing of Metallic Materials. 